\title{
The diet of Metaschizotherium bavaricum (Chalicotheriidae, Mammalia) from the MN 5 of Sandelzhausen (Germany) implied by the mesowear method
}

\author{
Ellen Schulz · Julia M. Fahlke
}

Received: 27 February 2007/Accepted: 7 August 2007/Published online: 10 February 2009

(c) Springer-Verlag 2009

\begin{abstract}
The genus Metaschizotherium is a Miocene member of the Schizotheriinae (Chalicotheriidae, Perissodactyla) and appears in the MN 5 of Southern Germany with the species M. bavaricum. The Chalicotheriidae have mostly been reconstructed as browsers. In this study, the mesowear method is applied to 11 upper premolars and molars of M. bavaricum from the Upper Freshwater Molasse locality of Sandelzhausen (MN 5). With this method the amount of abrasive and attritive dental wear is investigated and thus it provides a time-averaged signature of food abrasiveness of ungulates. Principal components analysis is performed on mesowear variables of M. bavaricum. This species is found to classify closest to extant mixed feeding ruminants. This indicates that the diet of $M$. bavaricum essentially included nonabrasive browse but also a certain amount of abrasive plant material. The composition of the diet of extant reference species indicates that this abrasiveness was most likely imposed by bark and whole branches. In the palaeoecological context of Sandelzhausen $M$. bavaricum occupied the dietary niche of a mixed feeder or an abrasion-dominated browser. A high degree of similarity is recognised between the mesowear patterns of M. bavaricum from Sandelzhausen and M. fraasi from the
\end{abstract}

E. Schulz ( $\square)$

Biozentrum Grindel und Zoologisches Museum, Universität Hamburg, Martin-Luther-King-Platz 3, 20146 Hamburg, Germany

e-mail: ellen.schulz@uni-hamburg.de

J. M. Fahlke

Steinmann-Institut für Geologie, Mineralogie und Paläontologie, Universität Bonn, Nussallee 8, 53115 Bonn, Germany

e-mail: jfahlke@yahoo.de
MN 6 of the Franconian Alb. This is interpreted as reflecting a similar dietary niche of the two species.

Keywords Metaschizotherium bavaricum .

Chalicotheriidae - Sandelzhausen · Mesowear .

Feeding adaptation $\cdot$ Middle Miocene

Kurzfassung Die Gattung Metaschizotherium ist ein miozäner Vertreter der Schizotheriinae (Chalicotheriidae, Perissodactyla) und tritt in der MN 5 von Süddeutschland mit der Art M. bavaricum auf. Generell werden die Chalicotheriidae meist als Browser rekonstruiert. In der vorliegenden Studie wird die Mesowearmethode auf 11 obere Prämolaren und Molaren von M. bavaricum aus Sandelzhausen (MN 5) angewandt. Mit dieser Methode wird der Anteil von abrasiver und attritiver Zahnabnutzung untersucht und dadurch ein zeitlich gemitteltes Abrasivitätssignal der der Nahrung von Ungulaten bestimmt. Mit den Mesowearvariablen von M. bavaricum wird eine Hauptkomponentenanalyse durchgeführt. Die Art wird bei den rezenten Mischköstlern nahe den rezenten Ruminantiern eingestuft. Dies zeigt eine Nahrung an, die im Wesentlichen aus einer nichtabrasiven Blattnahrung und zusätzlich einem bedeutenden Anteil von abrasivem Pflanzenmaterial bestand. Aufgrund der Zusammensetzung der Nahrung der rezenten Vergleichsarten wird geschlussfolgert, dass die Abrasivität höchstwahrscheinlich auf Rinde und ganze Äste zurückzuführen ist. Im paläoökologischen Kontext der Fundstelle Sandelzhausen besetzt $M$. bavaricum somit die ernährungsökologische Nische eines Mischkostfressers bzw. abrasionsdominierten Konzentratselektierers. Eine hohe Ähnlichkeit wird zwischen dem Mesowearsignal von M. bavaricum aus Sandelzhausen und M. fraasi aus der MN 6 der Fränkischen Alb festgestellt. Dies wird als ähnliche Nahrungsanpassung der zwei Arten interpretiert. 
Schlüsselwörter Metaschizotherium bavaricum .

Chalicotheriidae - Sandelzhausen - Mesowear .

Nahrungsanpassung · Mittelmiozän

\section{Introduction}

The Chalicotheriidae belong to the Ancylopoda within the Perissodactyla (Hooker and Dashzeveg 2004). Ever since they were first mentioned (cf. Cuvier 1823), their uncommon anatomy has caught the attention of biologists and palaeontologists. The Chalicotheriidae are known in the Old World and North America from the Palaeogene onwards to the early Pleistocene (Coombs 1989). Two subgroups, the Chalicotheriinae and the Schizotheriinae, are distinguishable by multiple morphological characters (e.g. Coombs 1989, 1998). In the Chalicotheriinae, the postcranial skeleton is strongly modified. The ungual phalanges are compressed laterally. The dental characters of the Chalicotheriinae are plesiomorphic, i.e. the molars are low-crowned in all species of this group (Coombs 1989). In contrast, the Schizotheriinae show a trend from low-crowned to highercrowned and to more elongated molars. The postcranium is less derived than in the Chalicotheriinae, and a typical perissodactyl proportion with approximately equally long forelimbs and hind limbs is retained (Coombs 1989).

Despite these differences, all chalicotheres are generally reconstructed as leaf browsers, with at least the more gorillalike Chalicotheriinae being able to erect themselves on their hind limbs and protract their arms to reach into the higher crowns of trees. The huge claws that must have covered the ungual phalanges, though differing between both subfamilies, are seen as a tool to obtain foliage by dragging or tearing down branches (e.g. Abel 1922; Coombs 1983, 1989; Heissig 1999; Koenigswald 1932; Zapfe 1976, 1979).

The chalicothere material from the Upper Freshwater Molasse deposits of Sandelzhausen, lower middle Miocene
(MN 5), was first described as Chalicotherium (Fahlbusch and Gall 1970). Later, its schizotheriine characters were recognised by Coombs (1974) and Fahlbusch (2003). In her revised diagnosis, Coombs (2009) reintroduces the species name Metaschizotherium bavaricum Koenigswald, 1932 for the Sandelzhausen chalicothere and gives a detailed morphological description of the cranial and postcranial material. For further details concerning the Chalicotheriidae and the exact systematic position of M. bavaricum see Coombs (2009).

The lack of modern analogue to the uniquely built Chalicotheriidae has always complicated the reconstruction of their ecology. In their recent study Schulz et al. (2007) tested the hypothesis of the browsing behaviour and shed some new light on the palaeoecology of this often abandoned fossil group. For this purpose the palaeodiets of different Central European chalicothere species, including $M$. bavaricum, were analysed, using the mesowear method (after Fortelius and Solounias 2000), a powerful tool to reconstruct the lifetime feeding behaviour of ungulates. Schulz et al. (2007) noted a substantial amount of abrasive plant material, like bark or whole branches, in the diet of the Chalicotheriidae and concluded a less abrasive diet for the Schizotheriinae compared with the Chalicotheriinae.

\section{Materials and methods}

This study is based on two last upper premolars $\left(\mathrm{P}^{4}\right)$ and nine upper molars $\left(\mathrm{M}^{1}, \mathrm{M}^{2}, \mathrm{M}^{3}\right)$ of $M$. bavaricum from the MN 5 of Sandelzhausen (Table 1). These teeth are also incorporated in the morphological study of this species (Coombs 2009) and a microwear analysis (Coombs and Semprebon 2005). The material is housed in the Bayerische Staatssammlung für Paläontologie and Geologie in Munich (BSP).

The mesowear method was first introduced by Fortelius and Solounias (2000) and improved by e.g. Kaiser et al.
Table 1 Mesowear scorings of Metaschizotherium bavaricum from Sandelzhausen; upper molars and premolars examined by mesowear method

\begin{tabular}{llllll}
\hline Specimen & $\begin{array}{l}\text { Tooth } \\
\text { position }\end{array}$ & Side & $\begin{array}{l}\text { Occlusal } \\
\text { relief }\end{array}$ & $\begin{array}{l}\text { Cusp shape } \\
\text { anterior }\end{array}$ & $\begin{array}{l}\text { Cusp shape } \\
\text { posterior }\end{array}$ \\
\hline BSPG 1959II11571 & $\mathrm{M}^{2}$ & Right & High & - & Sharp \\
BSPG 1959II11573 & $\mathrm{P}^{4}$ & Right & High & Round & Sharp \\
BSPG 1959II11612 & $\mathrm{M}^{2}$ & Left & High & Round & Blunt \\
BSPG 1959II11614 & $\mathrm{M}^{2}$ or $\mathrm{M}^{3}$ & Left & High & Sharp & - \\
BSPG 1959II11621 & $\mathrm{M}^{2}$ & Right & High & - & Round \\
BSPG 1959II11624 & $\mathrm{M}^{2}$ & Right & High & Round & Round \\
BSPG 1959II11630 & $\mathrm{M}^{1}$ & Right & High & Round & Sharp \\
BSPG 1959II2507 & $\mathrm{P}^{4}$ & Left & High & - & - \\
BSPG 1959II2507 & $\mathrm{M}^{1}$ & Left & High & Round & Round \\
BSPG 1959II2507 & $\mathrm{M}^{2}$ & Left & High & Round & Round \\
BSPG 1959II2507 & $\mathrm{M}^{3}$ & Left & High & - & - \\
\hline
\end{tabular}




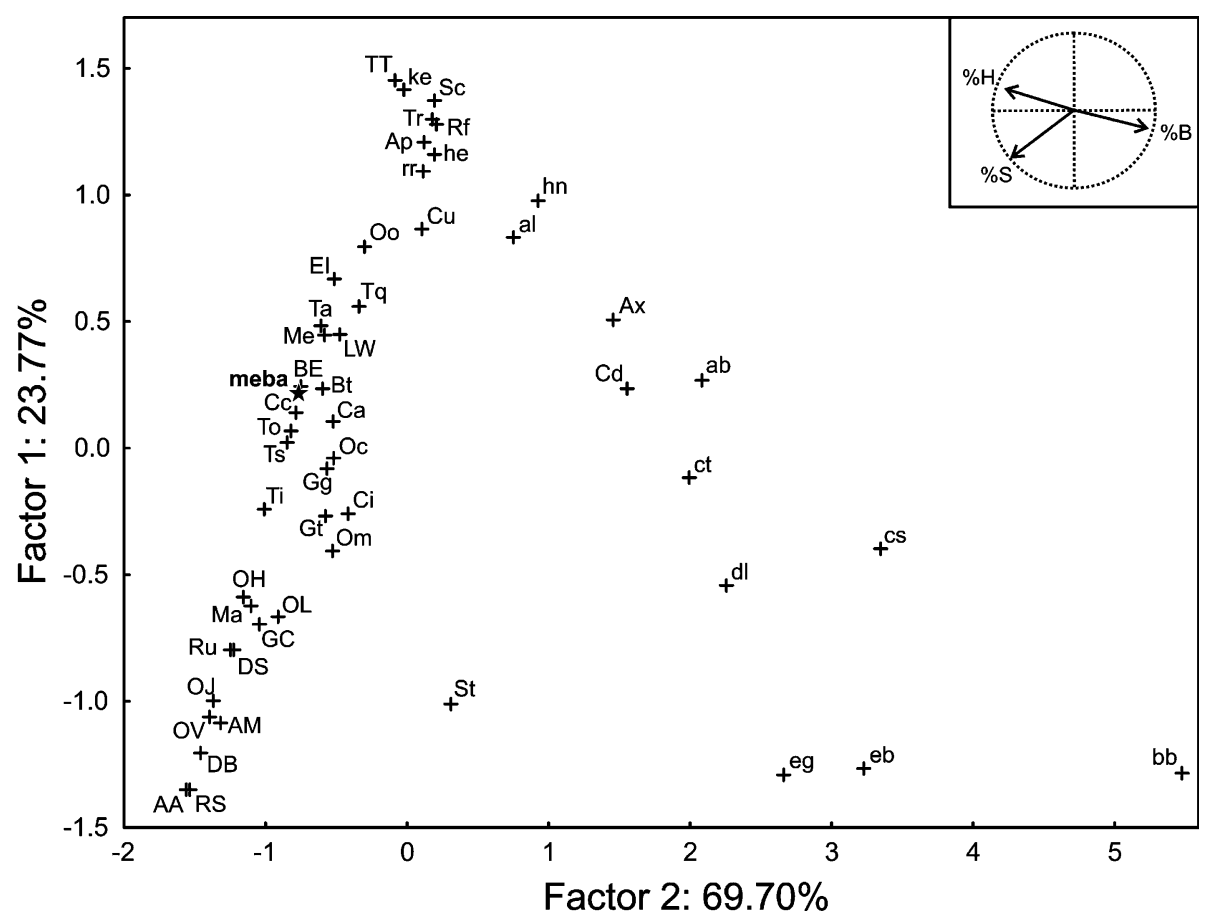

Fig. 1 Principal components analysis based on a subset of "typical" and "no particular class" species of the "CONS" dietary classification after Fortelius and Solounias 2000. The subset comprises groups of browsing (upper case only), mixed feeding (upper and lower case) and grazing species (lower case only). meba, Metaschizotherium bavaricum from Sandelzhausen (asterisk), $\mathrm{AA}=$ Alces alces, $\mathrm{ab}=$ Alcelaphus $\quad$ buselaphus, $\quad \mathrm{al}=$ Alcelaphus lichtensteini, $\mathrm{AM}=$ Antilocapra americana, $\mathrm{Ap}=$ Axis porcinus, $\mathrm{Ax}=$ Axis axis, $\mathrm{bb}=$ Bison bison, $\mathrm{BE}=$ Tragelaphus eurycerus, $\mathrm{Bt}=$ Budorcas taxicolor, $\mathrm{Ca}=$ Capricornis sumatraensis, $\mathrm{Cc}=$ Cervus canadensis, $\mathrm{Cd}=$ Cervus duvauceli, $\mathrm{Ci}=$ Capra ibex, $\mathrm{cs}=$ Ceratotherium simum, $\quad \mathrm{ct}=$ Connochaetes taurinus, $\mathrm{Cu}=$ Cervus unicolor, $\mathrm{DB}=$ Diceros bicornis, $\mathrm{dl}=$ Damaliscus. lunatus, $\mathrm{DS}=$ Dicerorhinus sumatrensis, eb = Equus burchellii, e.g = Equus grevyi,

(2000), Franz-Odendaal and Kaiser (2003), Kaiser and Fortelius (2003) and Kaiser and Solounias (2003). The method uses the differences in wear patterns on the occlusal surfaces of cheek teeth, caused by abrasion (foodtooth contact) or attrition (tooth-tooth contact), to identify dietary adaptations in ungulates. Two variables of the leading edge of the ectolph are analysed: the cusp shape, which can be sharp (S), round (R) or blunt (B), and the occlusal relief, which is either high $(\mathrm{H})$ or low (L). Usually only the sharper of the two buccal cusps is used in the analysis. In the application of the mesowear method to $M$. bavaricum, both the anterior and the posterior cusps had to be considered due to the small sample size (11 teeth). Compared with microwear, mesowear patterns reflect the diet of a longer time period (Kaiser and Schulz 2006, Schulz et al. 2007).

The teeth are examined with naked eye and then using a low-magnification $(10 \times)$ hand lens. The observed parameters $\% \mathrm{H}, \% \mathrm{~S}$, and $\% \mathrm{~B}$ are transformed to two
$\mathrm{EI}=$ Ammodorcas clarkei, $\mathrm{GC}=$ Giraffa cameloparlis, $\mathrm{Gg}=$ Gazella granti, $\mathrm{Gt}=$ Gazella thomsoni, he = Hippotragus equinus, $\mathrm{hn}=$ Hippotragus niger, $\mathrm{ke}=$ Kobus ellipsiprymnus, $\mathrm{LW}=$ Litocranius walleri, $\mathrm{Ma}=$ Antidorcas marsupialis, $\mathrm{Me}=$ Aepyceros melampus, $\mathrm{Oc}=$ Ovis canadensis, $\mathrm{OH}=$ Odocoileus hemionus, $\mathrm{OJ}=$ Okapia johnstoni, $\mathrm{OL}=$ Capreolus capreolus, $\mathrm{Om}=$ Ovibos moschatus, oo = Ourebia ourebi, OV = Odocoileus virginianus, $\mathrm{rf}=$ Redunca fulvorufula, $\mathrm{rr}=$ Redunca redunca, $\mathrm{RS}=$ Rhinoceros sondaicus, $\mathrm{Ru}=$ Rhinoceros unicornis, $\mathrm{sc}=$ Syncerus caffer, $\mathrm{St}=$ Saiga tatarica, $\mathrm{Ta}=$ Tragelaphus angasi, $\mathrm{Ti}=$ Tragelaphus imberbis, To = Taurotragus oryx, $\mathrm{Tq}=$ Tetracerus quadricornis, $\mathrm{Tr}=$ Boselaphus tragocamelus, $\mathrm{Ts}=$ Tragelaphus scriptus, $\mathrm{TT}=$ Tragelaphus strepsiceros

dimensionless factors in a principal components analysis (PCA, Fig. 1, using the software Statistica 7.1) and compared with the ones of a set of wild-shot adult ungulate specimens representing 61 extant species (after Fortelius and Solounias 2000). Fossil specimens are included as supplementary data. Principal components analysis is chosen because it detects grouping and correlation of the variables (see also Kaiser and Schulz 2006). We use the conservative classification categories (CONS) of grazers, browsers and mixed feeders established by Fortelius and Solounias (2000). In this classification species are distinguished by the ad hoc classifying variable class with the values "no particular class" (no), "typical of its dietary class" (typical) and "minute abraded brachydont" (mabra). We only consider species according to the first two classes. For better comparability bar charts of the percentages of the single parameters $\mathrm{H}, \mathrm{L}, \mathrm{S}, \mathrm{R}$ and $\mathrm{B}$ are calculated, also using Systat 11.0 (Fig. 2). For further details of the mesowear method consult Kaiser (2009). 
Fig. 2 Bar charts showing percentages of the mesowear parameters of

Metaschizotherium bavaricum in comparison with selected grazing, mixed feeding and browsing species. $B$ blunt; $H$ high; $L$ low; $R$ round; $S$ sharp

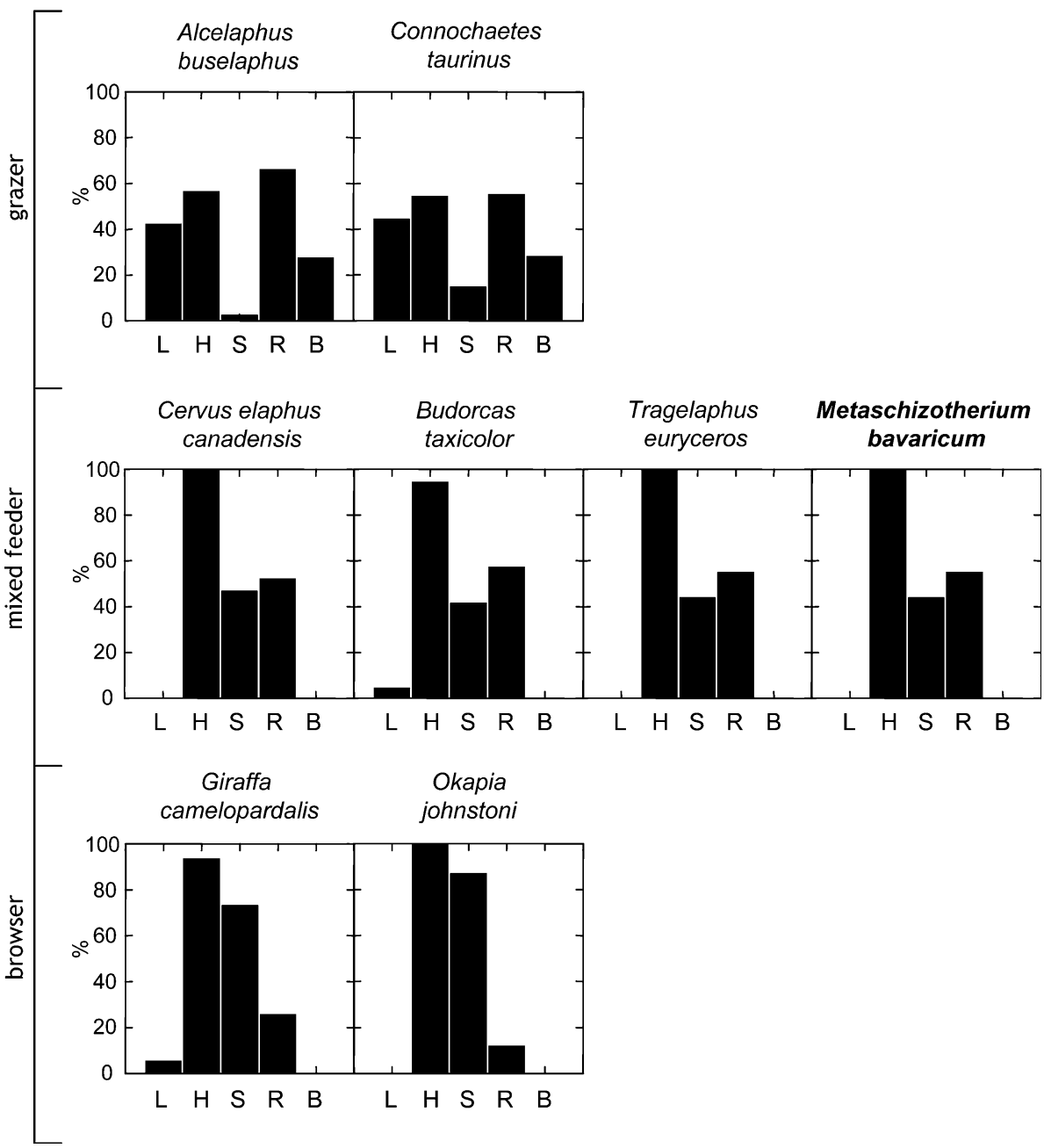

Table 2 Statistics of the PCA: correlation between factors and variables are given as factor loadings according to the mesowear variable $\% \mathrm{H}=$ percentage high, $\% \mathrm{~S}=$ percentage sharp, $\% \mathrm{~B}=$ percentage blunt

\begin{tabular}{lccl}
\hline & Factor 1 & Factor 2 & Statistic \\
\hline$\% \mathrm{H}$ & 0.322 & -0.897 & Factor loadings \\
$\% \mathrm{~S}$ & -0.748 & -0.663 & Factor loadings \\
$\% \mathrm{~B}$ & -0.225 & 0.920 & Factor loadings \\
Eigenvalue & 0.71 & 2.09 & Correlation matrix \\
Cumulative eigenvalue & 2.80 & 2.09 & Correlation matrix \\
Variance $(\%)$ & 23.77 & 69.70 & Correlation matrix \\
\hline
\end{tabular}

The eigenvalue, the cumulative eigenvalue and the percentage variance of the factors are given as characterisation of the correlation matrix

\section{Results}

All tooth specimens of $M$. bavaricum are high in relief (Table 1 ); $44.4 \%$ of the cusps are sharp, 55.6\% are round and $0 \%$ are blunt (Fig. 2). The factor loadings of the PCA represent the differentiation between and within the feeding groups. Factor 1 (eigenvalues; 23.77\%) differentiates browsers from mixed feeders, and factor 2 (eigenvalues; $69.7 \%$ ) differentiates these two from grazers (Fig. 1; Table 2). Browsers differ from mixed feeders and grazers along the axis of factor 1 in having a higher number of sharp cusps. Grazers differ from browsers and mixed feeders along the axis of factor 2 in having a higher number of blunt cusps. Compared to a one-dimensional cluster tree the PCA shows two dimensions: the grouping and the correlation of the variables. In the PCA $M$. bavaricum plots among the mixed feeders (Fig. 1). Similarities are found in the amount of high occlusal relief in combination with the percentages of the cusp shapes in the mesowear signal of the "typical" mixed feeder Cervus elaphus canadensis (\%high $=100$, $\%$ low $=0, \%$ sharp $=47.3, \%$ round $=52.7, \%$ blunt $=0$ ), the "no particular class" mixed feeder Budorcas taxicolor $(\%$ high $=95, \%$ low $=5, \%$ sharp $=42.1, \%$ round $=57.9$, $\%$ blunt $=0$ ) and the "no particular class" browser Tragelaphus euryceros $\quad(\%$ high $=100, \quad \%$ low $=0$, $\%$ sharp $=44.5, \%$ round $=55.5, \%$ blunt $=0)($ Figs. 1,2$)$. At a slightly more distant level it is linked to Capricornis 
sumatraensis $(\%$ high $=100, \%$ low $=0, \%$ sharp $=45.4$, $\%$ round $=50, \quad \%$ blunt $=4.6)$ and Taurotragus oryx $(\%$ high $=100, \%$ low $=0, \%$ sharp $=50, \%$ round $=50$, $\%$ blunt $=0$ ), which are classified within the "typical" mixed feeders (after Fortelius and Solounias 2000) (Fig. 1).

Compared to the cusp shape of "typical" browsers such as the giraffe (Giraffa camelopardalis) (\%high $=94$, $\%$ low $=6$, \%sharp $=73.7, \%$ round $=26.3$, \%blunt $=0$ ), and the okapi (Okapia johnstoni $) \quad(\%$ high $=100$, $\%$ low $=0, \%$ sharp $=87.5, \%$ round $=12.5 \%$ blunt $=0$ ) the Sandelzhausen material has significantly less sharp and more round cusp shapes (Fig. 2). In contrast to the grazing hartebeest Alcelaphus buselaphus and the blue wildebeest Connochaetes taurinus the specimens of M. bavaricum have higher reliefs and sharper cusp shapes (Fig. 2). Therefore, the mesowear signal of the Sandelzhausen specimens resembles neither that of a grazer nor that of a browser. This identifies $M$. bavaricum as a mixed feeder.

The mesowear results of M. fraasi, Anisodon grande and Chalicotherium goldfussi indicate an affinity to a more abrasive diet for A. grande and C. goldfussi, while $M$. fraasi has a mixed diet similar to that of $M$. bavaricum (Schulz et al. 2007).

\section{Discussion}

The dental mesowear pattern of M. bavaricum is similar to that of the bongo (Tragelaphus euryceros), the takin (Budorcas taxixolor), the wapiti (Cervus elaphus canadensis) and the serow (Capricornis sumatraensis). The bongo and the takin both inhabit dense forests and feed on leaves, twigs and shoots (Nowak 1999, Schaller et al. 1986). The serow lives in dense coniferous forest, open hardwood forests, chaparral and grasslands (Skovlin 1982) and feeds on grass, shoots and leaves (Nowak 1999) with a graze component of $20 \%$ and a browse component of $70 \%$ (Van Wieren 1996). The feeding preferences of the wapiti vary seasonally from grazing to browsing. According to Nelson and Leege (1982) the wapiti feeds on grass in spring and autumn and browses on forbs, woody plants, shrubs and conifers in the summer and winter. Therefore, it is suggested that $M$. bavaricum may have been a seasonal mixed feeder. This would be in accordance with the probably increasing seasonality discussed by Eronen and Rössner (2007) for the MN 5 of the Molasse Basin. Compared to the closest "typical" and "no particular class" extant species (Fortelius and Solounias 2000) we presume leaves and possibly shoots of dicotyledons to be the soft component in the diet of M. bavaricum.

Grassland habitats were not yet very widespread in the lower middle Miocene (Agustí and Antón 2002; Fortelius et al. 1996; Bernor et al. 1996). Therefore, the importance of grass in the diet of $M$. bavaricum is considered low, and other abrasive plant material must have caused the respective dietary signal.

Our data thus confirm a mixed feeding diet as also assumed by Coombs and Semprebon (2005) and Coombs (2009), who analysed the microwear signatures of chalicotheriines and schizotheriines (among these M. bavaricum) and compared them with those of extant fruit browsers and seasonal or regional mixed feeders. However, based on our extensive comparison with extant mixed feeders, fibrous and tough material such as bark and twigs may have been a more important component in the diet of M. bavaricum than fruit. This is supported by the results of enamel stable isotope values of $\delta^{13} \mathrm{C}$ and $\delta^{18} \mathrm{O}$ (Tütken and Vennemann 2009) who place M. bavaricum in a forested environment but exclude fruit and seeds as a major food source.

Coombs and Semprebon (2005) and Coombs (2009) found coarser microwear in Central European chalicotheriines than in the Schizotheriinae. This again is in agreement with the more abrasion-dominated diet found in Anisodon grande and the far more abrasive diet assumed for Chalicotherium goldfussi (Schulz et al. 2007). Generally, the mesowear method is used to see a lifetime dietary signal, in contrast to the microwear method, which gives an indication for the last few meals of an individual (Teaford and Oyen 1989). Therefore, differences between microwear and the mesowear results (Schulz et al. 2007) may have been caused by other factors such as seasonality of food availability.

For its occurrence in the rather humid palaeoenvironment of the Upper Freshwater Molasse and for the brachydont morphology of its molars, M. fraasi has hitherto been considered a leaf browser for a long time (cf. Koenigswald 1932). Thus, its assignment to the mixed feeders and the similarity to the mesowear signal of M. fraasi from the karstic plateau of the Franconian Alb (Petersbuch, MN 6) are quite unexpected. To explain this mixed feeding habit, two hypotheses may be suggested. Possibly, these schizotheriine chalicotheres may have occupied a large home range or covered large distances to exploit the respective plant material provided. Such a migratory behaviour would be in accordance with the retained typically perissodactyl body proportions of the schizotheriines. Another hypothesis is that M. bavaricum was a local resident and changed its food source on a seasonal basis. However, quadrupedal locomotion and obtaining food without erecting on the hind limbs would be most likely for $M$. bavaricum.

The Sandelzhausen ruminants are interspersed in the browser spectrum, and always plot close to a reference species with a pure browsing adaptation (Kaiser 2009). The composition of dietary traits in the Sandelzhausen ruminant 
fauna is thus different from what Kaiser and Rössner (2007) found in the Molasse Basin ruminant community, where they report a more abrasion-dominated dietary trait in Dorcatherium guntianum, D. crassum and Dicrocerus elegans. Another mixed feeder or probable opportunistic "dirty browser," as termed by Kaiser (2009), occurring in the MN 5 of Sandelzhausen is Anchitherium aurelianense. For this species Kaiser (2009) also indicates a less abrasive diet similar to that of M. bavaricum. The Upper Freshwater Molasse wetland environment included a wide range of habitats (Eronen and Rössner 2007; Göhlich 2002; Reichenbacher and Prieto 2006; Reichenbacher et al. 2004; Rössner 2004, 2006; Sach 1999; Sach et al. 2003; Schwarz and Reichenbacher 1989). The local species diversity was increasing in the MN 5, which is seen in the changes of dietary adaptations from soft browsing to more abrasive food in faunal communities (Eronen and Rössner 2007). Therefore we must consider that the more abrasive mixed feeding signal of $M$. bavaricum results from the occupation of a food niche to reduce competition with ruminants and A. aurelianense.

In conclusion, a quite opportunistic feeding behaviour is likely for M. bavaricum and may also be assumed for other schizotheriines based on the shared less abrasive mesowear signal and the less specialized postcranial skeleton (compared to the Chalicotheriinae). To propose a change in habitat preference from humid to more open within the genus Metaschizotherium (M. wetzleri, MN 2 to $\mathrm{MN} 4$; M. bavaricum, MN 5; M. fraasi, MN 6 to MN 7), far more research on the feeding ecology of chalicotheres needs to be done, including the increase of the number of specimens examined by both microwear and mesowear methods.

Acknowledgments First, we would like to thank Gertrud E. Rössner (Department für Geo- und Umweltwissenschaften, Munich) for inviting us to contribute to this volume. Kurt Heissig (BSPG, Munich) is gratefully acknowledged for access to the fossil material. We are also indebted to Thomas M. Kaiser (Biozentrum Grindel und Zoologisches Museum, Hamburg) for his support and constructive suggestions. Margery C. Coombs (Biology Department, University of Massachusetts, Amherst) and P. Martin Sander (Steinmann-Institut für Geologie, Mineralogie und Paläontologie, Bonn) are thanked for fruitful discussions and Sophia Lugard (International School, Hamburg) for her help improving the English. Gildas Merceron and an anonymous reviewer are thanked for their constructive comments and improvement of the manuscript.

\section{References}

Abel, O. 1922. Lebensbilder aus der Tierwelt der Vorzeit, 643. Fischer: Jena.

Agustí, J., and M. Antón. 2002. Mammoths, Sabertooths and Hominids: 65 Million Years of Mammalian Evolution in Europe, 328. Columbia University Press: Cloth.

Bernor, R.L., V. Fahlbusch, P. Andrews, H. De Bruijn, M. Fortelius, F. Rögl, F.F. Steininger, and L. Werdelin. 1996. The Evolution of Western Eurasian Neogene Mammal Faunas: A Chronologic, Systematic, Biogeographic, and Paleoenvironmental Synthesis. In The Evolution of Western Eurasian Neogene Mammal Faunas, ed. R.L. Bernor, V. Fahlbusch, and H.-W. Mittmann, 449-469. New York: Columbia University Press.

Coombs, M.C. 1974. Ein Vertreter von Moropus aus dem europäischen Aquitanien und eine Zusammenfassung der europäischen postoligozänen Schizotheriinae (Mammalia, Perissodactyla, Chalicotheriidae). Sitzungsberichten der Österreichischen Akademie der Wissenschaften, Mathematik-naturwissenschaft Klasse (Abt. I) 182:273-288.

Coombs, M.C. 1983. Large mammalian clawed herbivores: a comparative study. Transactions of the American Philosophical Society 73(7):1-96.

Coombs, M.C. 1989. Interrelationships and diversity in the Chalicotheriidae. In The Evolution of Perissodactyls, ed. D.R. Prothero, and R.M. Schoch, 438-457. New York: Clarendon/Oxford University Press.

Coombs, M.C. 1998. Chalicotherioidea. In Evolution of Tertiary Mammals of North America 1. Ungulates and Ungulatelike Mammals, Terrestrial Carnivores, ed. C.M. Janis, K.M. Scott, and L.L. Jacobs, 560-568. Cambridge: Cambridge University Press.

Coombs, M.C. 2009. The chalicothere Metaschizotherium bavaricum (Perissodactyla, Chalicotheriidae, Schizotheriinae) from the early middle Miocene (MN 5) Lagerstätte of Sandelzhausen (Germany): description, comparison, and paleoecological significance. In Fossil lagerstätte Sandelzhausen (Miocene, southern Germany), Contributions to the fauna. Paläontologische Zeitschrift, eds. Rössner, G.E., and U.B. Göhlich. 83 (1).

Coombs, M.C., and G.M. Semprebon. 2005. The diet of chalicotheres (Mammalia, Perissodactyla) as indicated by low magnification stereoscopic microwear analysis [abstract]. Journal of Vertebrate Paleontology 25(Suppl 3):47A.

Cuvier, G. 1823. Recherches sur les Ossements Fossiles 5(I), 405. Paris.

Eronen, J.T., and G.E. Rössner. 2007. Wetland paradise lost: Miocene community dynamics in large herbivorous mammals from the German Molasse Basin. Evolutionary Ecology Research 9:471494.

Fahlbusch, V. 2003. Die miozäne Fossil-Lagerstätte Sandelzhausen. Die Ausgrabungen 1994-2001. Zitteliana (A) 43:109-122.

Fahlbusch, V., and H. Gall. 1970. Die obermiozäne Fossil-Lagerstätte Sandelzhausen. 1. Endeckung, Geologie, Faunenübersicht und Grabungsbericht für 1969. Mitteilungen Bayerischen Staatsammlung für Paläontologie und historische Geologie 10:365-396.

Fortelius, M., and N. Solounias. 2000. Functional characterization of ungulate molars using the Abrasion-Attrition wear gradient: A new method for reconstructing paleodiets. American Museum of Natural History Novitates 3301:1-36.

Fortelius, M., L. Werdelin, P. Andrews, R.L. Bernor, A. Gentry, L. Humphrey, H.-W. Mittmann, and S. Viratana. 1996. Provinciality, Diversity, Turnover, and Paleoecology in Land Mammal Faunas of the Later Miocene of Western Eurasia. In The Evolution of Western Eurasian Neogene Mammal Faunas, ed. R.L. Berno, V. Fahlbusch, and H.-W. Mittmann, 414-448. New York: Columbia University Press.

Franz-Odendaal, T.A., and T.M. Kaiser. 2003. Differential mesowear in the maxillary and mandibular cheek dentition of some ruminants (Artiodactyla). Annales Zoologici fennici 40:395-410.

Göhlich, U.B. 2002. The Avifauna of the Miocene Fossil-Lagerstätte Sandelzhausen (Bavaria, Southern Germany). Zitteliana 22:169190.

Heissig, K. 1999. Family Chalicotheriidae. In The Miocene Land Mammals of Europe, ed. G.E. Rössner, and K. Heissig, 189-292. München: Pfeil. 
Hooker, J.J., and D. Dashzeveg. 2004. The Origin of Chalicotheres (Perissodactyla, Mammalia). Paleontology 47(6):1363-1386.

Kaiser, T.M. 2009. Anchitherium aurelianense (Equidae, Mammalia) a brachydont "dirty browser" in the community of herbivorous large mammals fron Sandelzhausen (lowest Middle Miocene, Germany). In Fossil lagerstätte Sandelzhausen (Miocene, southern Germany): Contributions to the fauna, eds. Rössner, G.E., and U.B. Göhlich. 83 (1).

Kaiser, T.M., and M. Fortelius. 2003. Differential mesowear in occluding upper and lower molars-opening mesowear analysis for lower molars and premolars in hypsodont equids. Journal of Morphology 258(1):67-83.

Kaiser, T.M., and G. Rössner. 2007. Dietary resource partitioning in ruminant communities of Miocene wetland and karst palaeoenvironments in Southern Germany. Palaeogeography, Palaeoclimatology, Palaeoecology 252(3-4):424-439.

Kaiser, T.M., and E. Schulz. 2006. Tooth wear gradients in zebra as an environmental proxy-A pilot study. Mitteilungen des Hamburgischen Zoologischen Museum und Institut 103:187210.

Kaiser, T.M., and N. Solounias. 2003. Extending the tooth mesowear method to extinct and extant equids. Geodiversitas 25(2):321345.

Kaiser, T.M., N. Solounias, M. Fortelius, R.L. Bernor, and F. Schrenk. 2000. Tooth mesowear analysis on Hippotherium primigenium from the Vallesian Dinotheriensande (Germany) A blind test study. Carolinea 58:103-114.

Koenigswald, G.H.R. 1932. Die Tertiären Wirbeltiere des Steinheimer Beckens: Metaschizotherium fraasi N. G. N. sp., ein neuer Chalicotheriide aus dem Obermiocän von Steinheim a. Albuch. Paleontographica Supplement-Band VIII:1-24.

Nelson, J.R., and T.A. Leege. 1982. Nutritional requirements and food habits. In Elk of North America: ecology and management, ed. J.A. Thomas, and D.E. Toweil, 323-367. Harrisburg: Stackpole Books.

Nowak, R.M. 1999. Walker's Mammals of the World, 6th edition, Volume 2, 1109-1451. Baltimore and London: The John Hopkins University Press.

Reichenbacher, B., and J. Prieto. 2006. Lacustrine fish faunas (Teleostei) from the Karpatian of the northern Alpine Molasse Basin, with a description of two new species of Prolebias Sauvage. Palaeontographica A 278(1-6):87-95.

Reichenbacher, B., M. Böhme, K. Heissig, J. Prieto, and A. Kossler. 2004. New approaches to assess biostratigraphy, palaeoecology and past climate in the North Alpine Foreland Basin during the late Early Miocene (Ottnangian, Karpatian). In The Middle Miocene environments and ecosystem dynamics of the Eurasian
Neogene (EEDEN), 249, eds. F.F. Steininger, J. Kovar-Eder, and M. Fortelius. 71-89.

Rössner, G.E. 2004. Community structure and regional patterns in late Early to Middle Miocene Ruminantia of Central Europe. Courier Forschungsinstitut Senckenberg 249:91-100.

Rössner, G. E. 2006. A community of Middle Miocene Ruminantia (Mammalian, Artiodactyla) from the German Molasse Basin. Palaeontographica A 278(1-6):101-110.

Sach, V. 1999. Litho- und biostratigraphische Untersuchungen in der Oberen Süßwassermolasse des Landkreises Biberach a. d. Riß (Oberschwaben). Stuttgarter Beiträge zur Naturkunde B 276:1167.

Sach, V., J. Gaudant, B. Reichenbacher, and M. Böhme. 2003. Die Fischfaunen der Fundstellen Edelbeuren-Maurerkopf und Wannenwaldtobel 2 (Miozän, Obere Süßwassermolasse, Süddeutschland). Stuttgarter Beiträge zur Naturkunde B 334:1-25.

Schaller, G.B., Q. Teng, W. Pan, Z. Qin, X. Wang, J. Hu, and H. Shen. 1986. Feeding behavior of Sichuan takin (Budorcas taxicolor). Mammalia 50:311-322.

Schulz, E., J.M. Fahlke, G. Merceron, and T.M. Kaiser. 2007. Feeding ecology of the Chalicotheriidae (Mammalia, Perissodactyla, Ancylopoda). Results from dental micro- and mesowear analyses. Verhandlungen des Naturwissenschaftlichen Vereins zu Hamburg 43:5-32.

Schwarz, J., and B. Reichenbacher. 1989. Die Charophytenflora der Kirchberger Schichten (Unter-Miozän). Geologica Bavarica 94:179-193.

Skovlin, J.M. 1982. Habitat requirements and evaluations. In Elk of North America: ecology and management, ed. J.W. Thomas, and D.E. Toweill, 369-413. Harrisburg: Stackpole Books.

Teaford, M.F., and O.J. Oyen. 1989. In vivo and in vitro turnover in dental microwear. American Journal of Physical Anthropology 80:73-81.

Tütken, T., and T. Vennemann. 2009. Stable isotope ecology of Miocene large mammals from Sandelzhausen, southern Germany. Paläontologische Zeitschrift 83(1).

Van Wieren, S.E. 1996. Digestive strategies in ruminants and nonruminants [PhD thesis], 191. Den Haag: Landbouwuniversiteit Wageningen.

Zapfe, H. 1976. Die Fauna der miozänen Spaltenfüllung von Neudorf a. d. March (ČSSR). Chalicotherium grande (Blv.). Sitzungsberichte der Österreichischen Akademie der Wissenschaften, mathematisch-naturwissenschaftliche Klasse, Abt. 1 185(5-7):91-112.

Zapfe, H. 1979. Chalicotherium grande (Blainv.) aus der miozänen Spaltenfüllung von Neudorf an der March (Děvinská Nová Ves), Tschechoslowakei. Neue Denkschriften des Naturhistorischen Museums in Wien 2:282. 